$\begin{gathered}\text { Науковий вісник Нлту України } \\ \text { Scientific Bulletin of UNFU } \\ \text { https://nv.nltu.edu.ua }\end{gathered}$
$\begin{array}{r}\text { https://doi.org/10.36930/40310110 } \\ \text { Article received 25.01.2021 p. } \\ \text { Article accepted 04.02.2021 p. } \\ \text { UDC 630*[681.7:722]:502.171 }\end{array}$

Н. М. Юрків, І. І. Дідович, Е. А. Кульчицька

Національний лісотехнічний університет Украйни, м. Львів, Украӥна

\title{
МЕТОДИКА РОЗРАХУНКУ РІВНЯ ЕКОЛОГІЧНОЇ БЕЗПЕКИ ЕКСПОРТНОЇ ДІЯЛЬНОСТІ ЛІСОГОСПОДАРСЬКИХ ПІДПРИЄМСТВ
}

Проаналізовано та обгрунтовано поняття еколого-безпечного експортного виробництва лісогосподарських підприємств, як такого, за якого фінансові надходження від реалізації експортної продукції $є$ на рівні, що дає змогу відшкодовувати витрати на виробництво і реалізацію цієї продукції, витрати на відтворення лісу і на відновлення корисних соціальних та екологічних функцій лісу, які внаслідок вирубок понесли відповідні втрати. Встановлено, що для забезпечення екологічно безпечного функціонування лісових екосистем у процесі експортної діяльності лісогосподарських підприємств фінансові надходження від реалізації експортної продукції повинні повністю компенсувати виробничі втрати (вилучені деревинні ресурси), а також втрати соціальних і екологічних функцій лісу. Систематизовано еколого-економічні фактори, які впливають на безпеку експортної діяльності лісогосподарських підприємств, а також проаналізовано величину і характер цього впливу. Запропоновано та обгрунтовано методику оцінювання рівня екологічної безпеки експортної діяльності, яка базується на розрахунку коефіцієнта рівня екологічної безпеки підприємства. Ця методика передбачає здійснення комплексного оцінювання безпеки експортної діяльності показниками, що враховують ступінь екологічної загрози від виробничого навантаження на лісові екосистеми в процесі виробництва лісопродукції на експорт і ступінь навантаження від експортної діяльності на соціальні та екологічні функції лісу. Запропонована методика розрахунку рівня екологічної загрози від експортної діяльності лісогосподарських підприємств з урахуванням впливу зазначених факторів дає змогу оцінити стан еколого-економічної безпеки експортної діяльності цих підприємств. Така оцінка слугуватиме передумовою для розроблення та прийняття підприємством необхідних управлінських рішень для підвищення ефективності експортної діяльності на засадах сталого розвитку. Запропоновану методику можна використати для оцінювання стану еколого-економічної безпеки експортної діяльності підприємств суміжних галузей національного господарства для прийняття ними адекватних управлінських рішень.

Ключові слова: екологічна безпека експортної діяльності; екологічно безпечне експортне виробництво; вплив на лісові екосистеми; навантаження на ліси в процесі заготівлі деревини; надходження від експорту лісопродукції; коефіцієнт рівня екологічної безпеки експортної діяльності.

\section{Вступ}

Важливою умовою діяльності лісогосподарських підприємств за сучасних умов $є$ недопущення порушень лісових екосистем відповідно до концепції сталого лісокористування. Однак підприємства для досягнення високої економічної ефективності в процесі своєї господарської діяльності часто порушують передбачені законодавством екологічні вимоги, нормативи та норми, що негативно впливає на екологічно безпечний стан навколишнього середовища.

3 огляду на те, що екологічно безпечним вважають такий стан навколишнього середовища, за якого порушення природних екосистем і виникнення негативних явищ для природного середовища є мінімальними та не виходять за межі вимог сталого розвитку, актуальним $є$ визначення та оцінювання величини впливу на лісові екосистеми господарської діяльності лісогосподарських підприємств способом розрахунку рівня екологічної безпеки такої діяльності.

Беручи до уваги наявну на сьогодні дію нормативних актів щодо заборони експорту круглого лісу, що спричинило істотне погіршення економічного стану лісогосподарських підприємств, важливим є дослідження ризиків від експортної діяльності. Оскільки для забезпечення конкурентоспроможності деревинної продукції на зовнішньому ринку вітчизняні виробники змушені використовувати сировину високої якості, яка відповідала б міжнародним стандартам і вимогам, експортна діяльність спричиняє вилучення $з$ лісових фондів більшої кількості та вищих сортів деревини, а також негативно впливає на лісові ділянки під час її заготівлі. Враховуючи це, заготівля деревини для реалізації на зовнішній ринок чинить відчутніший вплив на запаси де-

\section{Інформація про авторів:}

Юрків Надія Миколаївна, канд. екон. наук, асистент, кафедра менеджменту зовнішньоекономічної діяльності. Email: borysnadia@ukr.net

Дідович Іван Іванович, канд. екон. наук, доцент, кафедра менеджменту зовнішньоекономічної діяльності. Email: ididovych@gmail.com; https://orcid.org/0000-0001-5000-3814

Кульчицька Евеліна Антоніївна, канд. екон. наук, доцент, кафедра менеджменту зовнішньоекономічної діяльності. Email: evelina@nltu.edu.ua; https://orcid.org/0000-0002-2373-853X

Цитування за ДСту: Юрків Н. М., Дідович І. І., Кульчицька Е. А. Методика розрахунку рівня екологічної безпеки експортної діяльності лісогосподарських підприємств. Науковий вісник НлтУ України. 2021, т. 31, № 1. С. 62-67.

Citation APA: Yurkiv, N. M., Didovych, I. I., \& Kulchytska, E. A. (2021). The method of calculating the environmental safety level of export activities of forestry enterprises. Scientific Bulletin of UNFU, 31(1), 62-67. https://doi.org/10.36930/40310110 
ревини та лісову екосистему загалом.

Тому для належного оцінювання своєї експортної діяльності лісогосподарським підприємствам доцільно володіти досконалою методикою розрахунку рівня екологічної безпеки, що дасть їм змогу здійснювати спрямоване управління такою діяльністю.

Об'єкт дослідження - екологічна безпека експортної діяльності лісогосподарських підприємств.

Предмет дослідження - науково-методичні та прикладні підходи до оцінювання рівня екологічної безпеки експортної діяльності лісогосподарських підприємств.

Мета роботи - розвиток наявних та встановлення нових підходів до методики оцінювання рівня екологічної безпеки експортної діяльності лісових підприємств.

Для досягнення зазначеної мети визначено такі основні завдання дослідження: обгрунтувати фактори, які впливають на стан екологічно безпечної експортної діяльності лісогосподарських підприємств; описати методики оцінювання рівня екологічної безпеки експортної діяльності лісогосподарських підприємств способом урахування впливу цих факторів на величину рівня безпеки, що дає змогу приймати адекватні стратегії управління діяльністю підприємствами.

Наукова новизна отриманих результатів дослідження - вперше запропоновано методику оцінювання рівня екологічної безпеки експортної діяльності лісогосподарських підприємств, що враховує, окрім виробничого навантаження на лісові екосистеми, ще й втрату лісами своїх соціальних та екологічних функцій.

Практична значущістьь результатів дослідження пропонована методика дає змогу оцінювати рівень екологічної безпеки експортної діяльності будь-якого підприємства, що у процесі цієї діяльності спричиняє вплив на довкілля.

Аналіз останніх досліджень та публікацій. Вплив на лісові екосистеми господарської діяльності підприємств для досягнення високої економічної ефективності досліджувало багато вчених. Зокрема, у працях [3, 4] визначено, що екологічно безпечний стан - це такий стан навколишнього середовища лісогосподарських підприємств, за якого неможливими є порушення природних екосистем і виникнення негативних явищ для життя та здоров'я людей.

Беручи до уваги те, що виробництво лісогосподарської продукції, зокрема на експорт, пов'язане зі значними навантаженнями на ліс i лісові території підприсмств, дослідження та аналіз природно-економічних аспектів екологічної безпеки експортної діяльності $\epsilon$ надзвичайно важливим чинником для формування екологічно спрямованого управління такою діяльністю.

Безпека експортної діяльності лісогосподарського підприємства є комплексним поняттям, що враховує одночасно такі аспекти: екологічні - відтворення і збереження екосистеми; соціальні- гармонійне поєднання штучно створеного людиною матеріально-інформаційного і природного середовища; економічні - відповідний економічний ефект за умови безпечного рівня навантаження на природні ресурси [12].

Для еколого-економічного оцінювання лісів академік Ю. Туниця запропонував враховувати такі важливі компоненти лісових ресурсів як безпосередньо деревинний запас та саму лісову ділянку, які й утворюють комплекс корисних функцій лісу [9]. Він сформулював сутність поняття еколого-економічної ефективності та довів, що господарська діяльність є недоцільною, якщо негативний екологічний ефект перевищує досягнутий економічний. Недоцільною вважають також спеціальну природоохоронну діяльність, якщо витрати на ії здійснення перевищують досягнутий позитивний ефект. Цей варіант дає від'ємний інтегральний екологічний ефект.

Розрахунок рівня екологічної безпеки лісового підприємства, що здійснює експорт деревинної продукції, повинен базуватися на врахуванні навантаження на екосистему від виробничого процесу заготівлі деревини на експорт із врахуванням усіх витрат цього процесу, зокрема і втрат не деревинних ресурсів лісу [7]. Оцінювання рівня екологічної безпеки діяльності підприємств викладено у працях учених Ю. Ю. Туниці, Л. М. Грановської, А. І. Карпука та ін. [3, 4, 9].

У багатьох наукових дослідженнях фундаментальним критерієм екологічно безпечного виробництва приймають критерій, що пов'язаний із ступенем ризику щодо завданого збитку природному середовищу $[2,5,6$, 11]. Ризики виробничого впливу суб'єкта господарювання на природне середовище можуть мінімізуватися, набуваючи екологічно безпечного рівня, тільки за умов, коли підприємство має фінансові, матеріальні, інформаційні, управлінські та інші ресурси для збереження або відновлення природного стану лісових територій [1].

Матеріали та методи дослідження. У дослідженні використовували базові положення сталого розвитку, наукові праці вітчизняних учених 3 проблем теорії та практики екологічно безпечного виробництва в лісовому господарстві, а також сучасні методи дослідження: аналізу та синтезу - для оцінювання впливу вилучення лісових ресурсів на екологічний стан лісових територій підприємства; експертних оцінок - під час формування системи факторів, що визначають рівень екологічності виробничої діяльності лісогосподарських підприємств.

\section{Результати дослідження та їх обговорення}

Кількісну оцінку екологічної безпеки господарської діяльності підприємства, зокрема експортного виробництва, за природними аспектами можна здійснити способом порівняння значень природоємкості (комплексне економічне, екологічне і соціальне навантаження на лісові ресурси) виробництва лісопродукції на експорт, тобто сукупністю обсягів господарського вилучення й ураження місцевих відновлюваних ресурсів I, включаючи забруднення середовища, і можливість залучення ресурсів підприємства для відновлення первозданних екосистем $T_{e}$. За умови, коли експортне виробництво здійснюють на екологічно безпечному рівні, величина цих показників $є$ однаковою, тобто $I=T_{e}$ [9].

Рівень екологічного навантаження від експорту на екосистему лісових підприємств доцільно оцінювати коефіцієнтом екологічної загрози, який можна визначити за такою формулою $[8,13]$ :

$$
k_{\text {e3 }}=I / T_{e} .
$$

Значення $k_{e з} \leq 1$ свідчать про екологічно безпечний стан експортного виробництва. За умови, коли $1<k_{e 3} \leq 2$, цей стан $є$ екологічно напруженим, а за умови, коли $k_{e s}>2$, стан вважають екологічно критичним.

Враховуючи те, що ліс $є$ народногосподарською цінністю із значним комплексом корисних ефектів, що ак- 
тивно використовуються суспільством, оцінювання рівня навантаження на ліси від експортної діяльності підприємства повинна містити розрахунок цілого комплексу показників (корисних функцій лісу). Комплекс корисних функцій лісу, що можуть перебувати під впливом експортного навантаження, охоплює [9]: здатність лісу створювати матеріальні блага, передусім, деревинну продукцію, яка і $є$ основою експортної діяльності; здатність лісових територій створювати необхідні умови для існування різних видів флори і фауни, що можуть зазнавати істотних змін у зв'язку з рубками на експорт; здатність виконувати комплекс соціальних функцій; здатність формувати і підтримувати загально-природний баланс (рельєф, водний баланс, клімат).

В експортній діяльності матеріальним носієм вартості є деревинний ресурс, який за умов концепції сталого розвитку потрібно відновлювати шляхом відтворення лісів. 3 огляду на сформовані у праці [9] висновки, експортна діяльність $є$ екологічно безпечною лише тоді, коли кошти від реалізації експортної продукції компенсують експлуатаційне навантаження саме на деревинний запас. Водночас негативні наслідки від експортної діяльності несуть і лісові ділянки, на яких безпосередньо проводилися рубки деревини. Здебільшого зменшується ефективність виконання лісовими територіями підприємства природоохоронних, природоутворювальних та соціальних функцій. Це зумовлює необхідність значних фінансових ресурсів, які потрібно вкладати у вартість експортної продукції, для забезпечення відновлення екологічних функції лісу.

Рівень навантаження від експортної діяльності визначається величиною втрат корисності усіх компонентів екосистеми підприємства. Для інтегральної оцінки рівня експортного навантаження на ліси виправданим може бути системний підхід, який передбачає лісові корисності як систему елементів, які потрібно оцінювати самостійно в певній послідовності, маючи на увазі, що кінцевий результат, з точки зору екологічної безпеки, може давати не тільки негативи, але й очевидні позитиви такої діяльності.

Комплексним показником безпечного рівня екологічного навантаження може бути коефіцієнт стану екологічної безпеки підприємства. Цей показник узагальнює та порівнює економічний ефект від використання лісових ресурсів підприємства і необхідні витрати на відновлення цих ресурсів.

Якщо згрупувати усі корисні властивості лісу в дві групи - виробничі компоненти лісу і соціальні та екологічні функції лісу, то кількісно і вартісно оцінити другу групу є дуже складно. Поряд з цим, потрібно розуміти, що ці функції виступають як певні засоби праці - здоров'я, інформативність суспільства, ефективність суспільного виробництва тощо. Отже, вони $є$ складовою частиною екологічної безпеки, рівень якої може зменшуватися.

Виробниче навантаження на лісові ресурси підприємства від експортної діяльності, на наш погляд,це витрати, які потрібно компенсувати для приведення лісових ресурсів до еколого-безпечного рівня, що передував початку виробництва експортної продукції. На рисунку описано витрати, які необхідно враховувати під час оцінювання виробничого навантаження на лісові екосистеми.

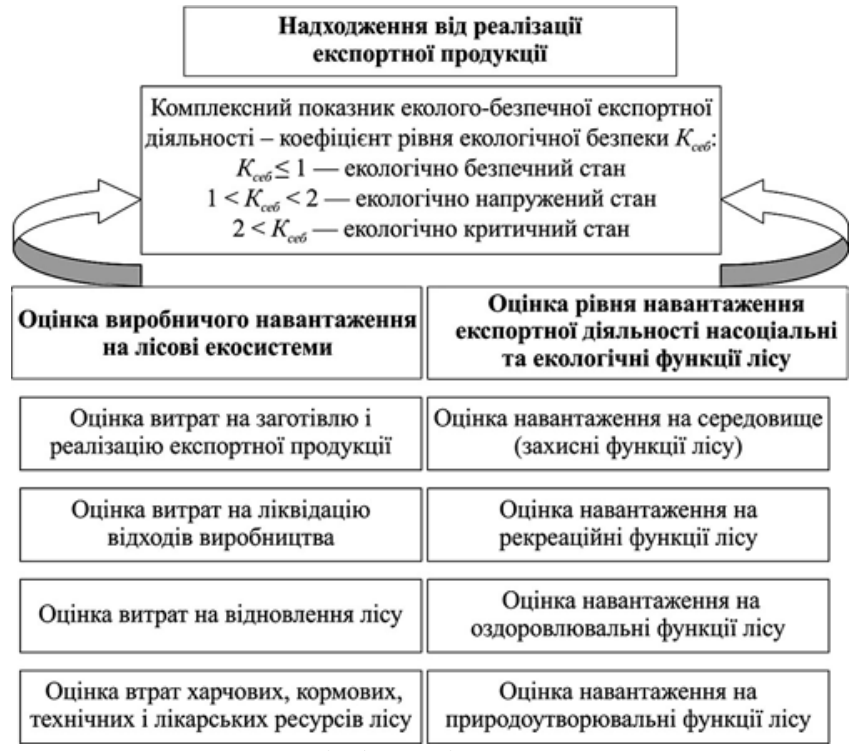

Рисунок. Систематизація факторів впливу на стан еколого-безпечної експортної діяльності лісогосподарських підприємств

Витрати на виробництво і реалізацію експортної продукції (повна собівартість експортної продукції) для забезпечення еколого-безпечного стану такої діяльності потрібно сприймати як суспільну працю, що перенесена в експортну продукцію і використана для реалізації необхідних заходів екологічної безпеки. Оскільки в ціну експортованої лісопродукції закладається нормативний дохід, який розраховують отримати підприємства від іiі реалізації, то повну собівартість виробництва і реалізації експортної продукції доцільно розраховувати за такою формулою [12]:

$$
C_{e}=\frac{Q_{e d}}{1+r / 100}
$$

де: $Q_{e д}-$ обсяг доходу від реалізації експортної продукції, грош. од.; $r$ - визначена норма прибутку, \%.

Витрати на ліквідацію і перероблення відходів виробництва експортованої деревинної продукції здебільшого враховують як витрати на підготовку лісових ділянок для молодих насаджень.

Втрачену вартість у відходах виробництва продукції на експорт доцільно визначити як суму добутків фактичного запасу деревини на ділянці, середньої ціни на сорти деревини на міжнародному ринку та розміру ділянки, що корегується коефіцієнтом безвідходності виробництва. Для кількісної оцінки таких втрат можна використати формулу

$$
L V_{в}=k_{p в \varepsilon} \cdot \sum_{i=1}^{N} \sum_{j=1}^{M} Q_{i j} \cdot P_{i j} \cdot S_{i j}, \text { грош. од., }
$$

де: $L V_{6}-$ вартість додаткових відходів від виробництва продукції на експорт, грош. од.; $Q_{i \mathrm{j}}-$ запас деревини $i$ го сорту на $j$-тій ділянці вирубок, $\mathrm{M}^{3} / г \mathrm{a} ; i=1,2, \ldots, N-$ кількість сортів деревини; $j=1,2, \ldots, M$-кількість ділянок вирубки; $P_{i j}$ - середня ціна на міжнародному ринку $i$-го сорту деревини на $j$-тій ділянці вирубок, євро $/ \mathrm{m}^{3}$; $S_{i j}$ - площа $j$-тої ділянки вирубок $i$-го сорту деревини, га; $k_{p в в}-$ коефіцієнт, що враховує рівень вартості відходів експортного виробництва.

Коефіцієнт, що враховує рівень вартості відходів експортного виробництва, можна розрахувати за такою формулою 


$$
k_{p 86}=\left(1-\frac{Q_{m n}}{Q_{n p}}\right) \cdot k_{p u},
$$

де: $Q_{m n}-$ обсяг товарної продукції, м³ $Q_{n p}$ - обсяг лісових ресурсів на розрахунковій площі вирубок, що пішли на виробництво продукції, м ${ }^{3} ; k_{p u}$ - коефіцієнт, що враховує рівень ціни відходів виробництва, порівняно 3 ціною товарної продукції.

Обсяг фінансових надходжень від експортної діяльності, необхідний для забезпечення еколого-безпечного рівня, можна визначити шляхом порівняння величини цих надходжень з витратами, необхідними для відновлення лісових насаджень.

Витрати на відновлення лісів складають основну частину компенсаційного внеску за навантаження від заготівлі експортної продукції.

Додаткові витрати на формування ділянок молодих насаджень, площі яких є більшими, ніж площі вирубок, пропонують враховувати коефіцієнтом стійкості молодих насаджень $k_{\text {смн. }}$. Значення цього коефіцієнта $\epsilon$ диференційованими, залежно від породи деревини, що враховує терміни досягнення якісних кондицій деревини певної породи. Якщо для термінів вирощування стиглої деревини в межах 40-50 років (береза, осика, граб) коефіцієнт стійкості молодих насаджень приймається на рівні $k_{c м н}=1,1$, то кожні наступні 20-30 років періоду дозрівання поріг стійкості повинен збільшуватися на 0,1. Тобто, для насаджень сосни, модрини, ялини, ялиці (термін дозрівання 70-90 років) коефіцієнт стійкості варто приймати $k_{c м н}=1,2$, а для дуба і бука (термін досягнення стиглості 100-120 років) $-k_{\text {смн }}=1,3$.

Витрати підприємства на відновлення лісів містять:

- витрати на підготовку ділянок для молодих насаджень;

- витрати на закупівлю посадкового матеріалу;

- витрати на роботи з висаджування саджанців та догляду за молодняком до 10-річного віку;

- витрат на лісогосподарювання в період росту деревини 3 10 років до необхідних якісних кондицій.

Кількісно оцінити витрати на відновлення лісів підприємства, що вилучені на виробництво експортної продукції, можна за формулою

$$
L V_{6 л}=S_{p} \cdot\left(C_{n \partial}+C_{3 c}+C_{в c}+C_{\text {догл }}\right) \cdot k_{c и н},
$$

де: $S_{p}-$ площі рубок для виробництва продукції, га; $C_{n \partial}-$ витрати на підготовку одного гектара ділянки для висаджування молодих насаджень, грош. од.; $C_{\text {зс }}-$ витрати на закупівлю саджанців, грош. од. (для одного га площ); $C_{6 c}-$ витрати на висаджування саджанців, грош. од. (на одному га площ); $C_{\text {догл }}-$ витрати на догляд за молодими насадженнями до 10 років, грош. од. (на одному га площ); $k_{\text {смн }}-$ коефіцієнт стійкості молодих насаджень.

Вилучення для виробництва експортної продукції значних площ стиглих лісів, що сформували впродовж тривалого періоду певні локальні екосистеми, значною мірою може вплинути на втрати недеревинних природних ресурсів лісу. Економічну оцінку 1 га недеревинної рослинності лісу, рекомендують розраховувати за формулою [7, 10]

$$
Z_{M}=\sum_{n=1}^{J} \sum_{t=1}^{T}\left(L_{n t}-C_{n t}-\Pi_{n t}^{H}\right) \cdot \alpha_{t} \cdot M_{n t} \cdot k_{t},
$$

де: $Z_{M}$ - загальна кількість (у вартісному вираженні) біомаси недеревинного походження, яку здатний генерувати 1 га лісової ділянки, що відведена під вирубки; $n-$ кількість видів економічно доступної рослинності, що є об'єктом оцінки; $t$ - тривалість розрахункового періоду, який визначається терміном заготівлі недеревної рослинності; $\bigsqcup_{n t}-$ ціна 1 кг продукції побічного користування лісом $n$-го виду в $t$-му році (без ПДВ); $C_{n t}-$ повна собівартість 1 кг продукції побічного користування лісом $n$-го виду в $t$-му році (без плати за спеціальне використання недеревної рослинності); $\Pi_{n t}^{t}-$ нормативний прибуток в ціні 1 кг продукції побічного користування лісом $n$-го виду в $t$-му році; $\alpha_{t}$ - коефіцієнт дисконту для $t$-го року; $M_{n t}$ - економічно доступні ресурси недеревної рослинності $i$-го виду в $t$-му році в кілограмах; $k_{t}$ - коефіцієнт екологічної шкоди (може визначатися, наприклад, втратою родючості грунту внаслідок його ущільнення тощо).

Водночас, якщо врахувати окремі фактори (недеревинна рослинність щорічно поновлюється без втручання людини; урожай можна збирати не один, а декілька разів протягом вегетаційного періоду впродовж тривалого часу (5-10 років); продуктивність недеревних ресурсів важко спрогнозувати за рахунок визначального впливу волого-температурних факторів; інтенсифікація обсягів заготівлі продукції побічного користування лісом прямо пропорційна збільшенню екологічної шкоди, що завдається лісовим біогеоценозам), то отримати за формулою (6) об'єктивний результат є надзвичайно складно через відсутність на лісогосподарських підприємствах повної звітності за цими показниками.

У разі врахування усіх видів виробничого навантаження експортної діяльності на лісові ресурси підприємства, узагальнений показник рівня експлуатаційного навантаження (коефіцієнт екологічної загрози виробничого навантаження від заготівлі продукції на експорт) пропонуємо визначати за формулою

$$
k_{\text {езвн }}=\frac{C_{e}+L V_{B}+L V_{8 \pi}+Z_{M}}{Q_{e \partial}}=\frac{Q_{e в H}}{Q_{e д}},
$$

де $Q_{е в н}-$ сумарне експортне виробниче навантаження на лісові ресурси підприємства.

Наведена методика розрахунку рівня екологічного навантаження від експортного виробництва дає змогу визначити лише економічну складову такого навантаження. Разом $з$ цим, вилучення деревини 3 екосистеми, як на рівні підприємства, так і на рівні регіону, може негативно вплинути на екологічні та соціальні функції лісу. Тому розрахунок цих витрат обов'язково потрібно здійснювати.

Грошова оцінка втрачених корисностей щодо задоволення фізіологічних і духовних потреб суспільства (соціальні функції лісу) є набагато складнішою. По-перше, загальноприродні (екологічні) функції лісу, такі як природозахисна і природоохоронна, часто вступають у протиріччя i не можна визначити їх тісний зв'язок i взаємозалежність. По-друге, соціальні функції реалізуються під конкретне соціальне замовлення i, значною мірою, визначаються традиціями місцевого населення щодо сприйняття духовних корисностей лісу і особливостями етноприродних зон. Це викликає необхідність диференційованого підходу під час оцінки небезпеки втрат корисностей для кожного регіону таких основних соціальних функцій лісу як рекреаційна, оздоровлювальна, навчально-виховна, інформаційна та естетична.

По-третє, соціально-екологічні функції лісів мають понад 100 різнопроявів у плані корисності як для окре- 
мої людини, так і для суспільства загалом. Визначити таку кількість індикаторів втрати корисностей та нормативних значень стану екологічної безпеки для такої кількості проявів соціальних функцій є досить складно.

Вперше пропонуємо до оцінювання екологічної безпеки підприємства враховувати не лише вартісні та кількісні показники виробничого впливу, але й втрати лісами соціальних та екологічних функцій унаслідок заготівлі деревини для реалізації на експорт. Оцінку еколого-безпечної експортної діяльності для соціальних і екологічних функцій лісу пропонуємо здійснювати, розраховуючи коефіцієнт екологічної загрози соціально-екологічним функціям за такою формулою:

$$
k_{\text {eзсеф }}=\frac{L V_{\text {ceф }}}{Q_{e d}}
$$

де: $L V_{c е ф}-$ величина втрат корисностей соціальних і екологічних функцій лісу у вартісному вираженні; $Q_{e д}-$ обсяги доходів від реалізації експортної продукції.

Експортне навантаження на соціальні та екологічні функції лісу підприємства (величина втрат соціальних і екологічних функцій лісу) у грошовому вираженні пропонуємо розраховувати за формулою

$$
L V_{\text {cep }}=\sum_{i=1}^{N} T_{i} f_{i k}
$$

де: $T_{i}$ - кількість дерев $i$-тої породи (одиниць соціальноекологічного потенціалу) в обсязі рубок, які можуть зберігати або формувати певні види соціальних і екологічних корисностей; $f_{i k}-$ грошова оцінка соціального і екологічного потенціалу дерева $i$-тої породи щодо $k$-тої соціальної та екологічної функції.

Кількість вилучених упродовж року під час рубок одиниць соціально-екологічних потенціалів (дерев певної породи) розраховують за формулою

$$
T_{i}=0,05 \cdot S \cdot g_{\partial},
$$

де: $S$ - площі рубок, передбачених для реалізації продукції на зовнішньому ринку (га); $g_{\partial}-$ кількість дерев (соціально-екологічних потенціалів) певної породи на 1 га.

Оцінювання рівня еколого-безпечної експортної діяльності лісогосподарського підприємства пропонуємо здійснювати за значенням коефіцієнта рівня екологіч-

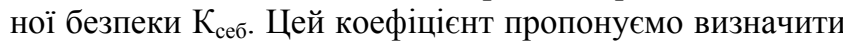
за формулами:

або

$$
\begin{gathered}
K_{\text {себ }}=k_{\text {езвн }}+k_{\text {езсеф }}, \\
K_{c е б}=\frac{C_{e}+L V_{B}+L V_{\text {вл }}+L V_{c e \phi}}{Q_{e д}} .
\end{gathered}
$$

Формули (11) і (12) передбачають комплексне врахування виробничого та соціально-екологічного навантаження на екосистему підприємства від виробництва експортної продукції.

\section{Висновки}

Встановлено, що фінансові надходження від реалізації експортної продукції потрібно спрямовувати для максимального відтворення лісових екосистем, які зазнали експлуатаційного впливу під час заготівлі деревини.

Вперше запропоновано методику оцінювання рівня екологічної безпеки експортної діяльності лісогосподарських підприємств шляхом комплексного урахування не тільки виробничого, а і соціально-екологічного навантаження на екосистему підприємства.

Розрахунок рівня екологічної безпеки дасть змогу лісогосподарському підприємству оцінити стан експортної діяльності, на підставі чого - розробити та прийняти необхідні управлінські рішення для підвищення ефективності експортної діяльності на засадах сталого розвитку.

\section{References}

1. Borys, N. M. (2013). Efektyvnist mignarodnoi torgivli derevynoy $\mathrm{z}$ urahuvaniam ekologichnogo faktora. Zbirnyk nayuk. prats Hmelnickiy KTEU: scientific journal, 6, 43-50. [In Ukrainian].

2. Girusov, E. V., Bobylev, S. N., \& Novoselov, A. L. (2015). Ekologia i ekonomika prirodopolzovania: uchebnik dlia vuzov. Moscow: UNITY-DANA. [In Russian].

3. Granovska, L. M. (2009). Ekologichno zbanansovane pryrodokorystuvania $\mathrm{v}$ umovah polifunkcionalnosti terytoriy. Kherson: HDU, 182 p. [In Ukrainian].

4. Karpuk, A. I., \& Shestak, M. L. (2015). Strategichni priorytety efektyvnogo rozvytku lisoresursoi sfery. Lutsk: PVD "Tverdynia", 124 p. [In Ukrainian].

5. Maksimiv, L. I. (2008). Management ustoichivogo lesnogo hozaistva v kontekstie postulatov ekologicheskoi ekonomiki. Ekonomika prirodopolzovania, 6, 107-114. [In Russian].

6. Motkin, G. A. (2010). Ekonomicheskaia ocenka sredoobrazuychyh funkciy ekosystem. Economics and mathematical methods, 1(46), 3-11. [In Ukrainian].

7. Syniakevich, I. M. (1992). Ekonomika galuzei lisovogo kompleksu. Kyiv: Znania, 320 p. [In Ukrainian].

8. Tunytsy, T. Yu., \& Borys, N. M. (2014). Poglyblenia zmistu ponatia "exportnyi potensial lisovyh pidrtyemstv" $\mathrm{v}$ konteksti vymog stalogo rozvytku. Visnyk Kharkivskogo nacionalnogo agrarnogo universitetu im. V. V. Dokuchaeva, 6, 76-82. [In Ukrainian].

9. Tunytsya, Yu. Yu. (2006). Eko-ekonomika i rynok: podolania superechnostei. Kyiv: Znania, 240 p. [In Ukrainian].

10. Yacuk, D. R. (2008). Problemy ocinky ekologo-ekonomichnoi efektyvnosti derevnyh i nedevnyh resursiv lisu. Scientific Bulletin of UNFU, 18(2), 80-85. [In Ukrainian].

11. Yuaremchuk, I. G. (2000). Ekonomika pryrodokorystuvania: navch. posibnyk. Kyiv: Prosvita. [In Ukrainian].

12. Yurkiv, N. M. (2019). Metodyka ekologo-ekonomichnogo ociniuania vyrobnichogo navantagenia na lisovi ekosystemy $\mathrm{v}$ procesi zagotivli derevyny na export. Scientific Bulletin of UNFU, 29(4), 38-42. https://doi.org/10.15421/40290407

13. Yurkiv, N., Didovich, I., \& Kulchytska, E. (2019). Vplyv ekologoekologichnyh faktoriv na bezpeku exportnoi dialnosti lisogospodarskyh pidpryemstv v umovah stalogo rozvytkuiv. Ekologo-ekonomichni problem u mignarodnii torgivli. Zbirnyk materialiv V naukovoi konferencii, Vol. 2, (pp. 7-21). Lviv: LNU. [In Ukrainian].

N. M. Yurkiv, I. I. Didovych, E. A. Kulchytska

Ukrainian National Forestry University, Lviv, Ukraine

\section{THE METHOD OF CALCULATING THE ENVIRONMENTAL SAFETY LEVEL OF EXPORT ACTIVITIES OF FORESTRY ENTERPRISES}

The concept of environmentally safe export production of forestry enterprises is analyzed and substantiated, as such, at which the financial income from the sale of export products is at a level that allows reimbursing the costs of production and sale of these products, costs of forest reproduction and restoration of useful social and environmental functions that have suffered corresponding los- 
ses as a result of felling. It is established that in order to ensure environmentally safe functioning of forest ecosystems in the process of export activity of forestry enterprises, financial revenues from the sale of export products must fully compensate for production losses (extracted wood resources) and loss of social and environmental functions of forests. The environmental and economic factors that affect the safety of export activities of forestry enterprises are systematized, and the nature of this impact is analyzed. The method of estimating the level of environmental safety of export activity is proposed and substantiated, which is based on the calculation of the coefficient of the level of environmental safety of the enterprise. This methodology involves a comprehensive assessment of the safety of export activities indicators that consider the degree of environmental threat from the production load on forest ecosystems in the production of forest products for export and the degree of load from export activities on social and environmental functions of forests. The proposed method of calculating the level of environmental threat from the export activities of forestry enterprises, taking into account the influence of these factors enables assessing the state of environmental and economic safety of export activities of these enterprises. This assessment will be a prerequisite for the development and making the necessary management decisions to improve the efficiency of export activities on the basis of sustainable development. The proposed method can be used to assess the state of environmental and economic safety of export activities of enterprises of related sectors of the economy to make adequate management decisions.

Keywords: environmental safety of export activity; environmentally friendly export production; impact on forest ecosystems; load on forests in the process of timber harvesting; proceeds from the export of timber products; coefficient of the ecological safety level of export activity. 